\title{
Antibacterial Activity of Guyabano, Ulasimang Bato, Sambong, and Tsaang Gubat Leaf Extracts against Common Drug-resistant Bacteria
}

\author{
Cecilia C. Maramba-Lazarte, ${ }^{1,2}$ Lolita L. Cavinta² and Ma. Carmelita L. Sara $^{1}$ \\ ${ }^{1}$ Department of Pharmacology and Toxicology, College of Medicine, University of the Philippines Manila \\ ${ }^{2}$ Institute of Herbal Medicine, National Institutes of Health, University of the Philippines Manila
}

\begin{abstract}
Background. Using plants as antimicrobials has long been a practice of traditional healers and validating these customs may lead to the discovery and development of useful herbal medicines.
\end{abstract}

Objective. This study aimed to determine the antibacterial activity of guyabano, tsaang gubat, sambong, and ulasimang bato against common pathogens.

Methods. Aqueous or alcoholic leaf extracts of the different medicinal plants were prepared. The solid agar dilution method was used to determine the MIC of guyabano, tsaang gubat, sambong, and ulasimang bato against common pathogens including Staphylococcus aureus, Echerichia coli, Streptococcus pneumoniae, Hemophilus influenzae, Pseudomonas aeruginosa, Salmonella typhi, and Shigella flexneri.

Results. The alcoholic leaf extract of guyabano showed moderate activity against oxacillin-sensitive $S$. aureus with an MIC of $5-6.3 \mathrm{mg} / \mathrm{mL}$. However, tsaang gubat did not exhibit any antibacterial activity for drug-resistant enteric organisms (S. typhi, S. flexneri, and E. coli) and S. aureus at a concentration of $25 \mathrm{mg} / \mathrm{mL}$. Even at a concentration of $100 \mathrm{mg} / \mathrm{mL}$, ulasimang bato failed to show any antibacterial activity against drug-resistant S. aureus, S. pneumonia, $H$. influenzae, E. coli, and P. aeruginosa. Sambong alcoholic extract had some antibacterial activity against penicillin-resistant S. pneumoniae with an MIC of $12.5 \mathrm{mg} / \mathrm{mL}$.

Conclusions. Guyabano alcoholic leaf extract showed moderate antibacterial activity against oxacillin-sensitive S. aureus. Sambong alcoholic extract likewise exhibited inhibitory activity against S. pneumoniae. However, tsaang gubat and ulasimang bato aqueous extracts failed to show significant antibacterial activity for the pathogens tested.

Key Words: antibacterial activity, guyabano, Anona muricata, tsaang gubat, Ehretia microphylla, Carmona retusa, sambong, Blumea balsamifera, ulasimang bato, pansit-pansitan, Peperomia pellucida

\section{INTRODUCTION}

Corresponding author: Cecilia C. Maramba-Lazarte, MD,

MScID, MScCT

Institute of Herbal Medicine

National Institutes of Health

University of the Philippines Manila

623 Pedro Gil St., Ermita, Manila 1000, Philippines

Email: ccmaramba@up.edu.ph
Bacterial infections remain to be an important cause of morbidity in the Philippines with respiratory, gastrointestinal and urinary tract infections still being very prevalent. ${ }^{1}$ Antibiotics have been used to treat bacterial infections and are considered one of the most important discoveries of the modern era. Unfortunately, because of extensive abuse and misuse of antibiotics both in humans and animals, rates of antimicrobial resistance have been increasing. According to a WHO Report in 2014, the top 7 common bacteria that cause serious diseases with widespread resistance include E.coli, S. aureus, $H$. influenzae, Shigella, P. aeruginosa, nontyphoidal Salmonella, Klebsiella, and N. gonorrhea. ${ }^{2}$ In the Philippines, Staphylococcus aureus, Pseudomonas aeruginosa, 
and Acinetobacter baumannii were reported to have high rates of resistance to conventional antibiotics. ${ }^{3}$ What is being feared now is an occurrence of a post-antibiotic era, wherein present antibiotics are ineffective against common diseases. Thus the efforts for discovery and development of new antimicrobials are still necessary in the modern era. To add to this problem, few pharmaceutical companies have invested in the discovery of new classes of antibacterials in the last 3 decades. ${ }^{4}$ This may be due to the enormous expenditures incurred for investigating new drugs, but the return of investment are much smaller for antibiotics which are only prescribed for a short period of time, compared to medications for lifestyle-related and chronic diseases such as diabetes and hypertension which are taken for very long periods of time.

Plants as sources of antimicrobials is an old concept which dates back to traditional medical sytems in numerous cultures. ${ }^{5}$ Herbal preparations have been used by traditional healers as antiseptics, as well as cures for pneumonia, diarrheas, and other bacterial infections. This may be a logical strategy since plants produce metabolites to protect themselves against microbes in the environment. ${ }^{3}$ Many modern day medicines and even antibiotics are also nature-derived or plant-based or plant-derived. ${ }^{4}$ Quinine and artemisinin are two success stories of antimalarial agents derived from the cinchona bark and Artemisia annua, respectively. ${ }^{6}$ Three types of antibacterials may be developed from plants: traditional antibacterials, inhibitors of multidrug resistance pumps, or compounds which target bacterial virulence. ${ }^{7}$

Four commonly used medicinal plants in the Philippines include guyabano, tsaang gubat, sambong, and ulasimang bato. Guyabano or Anona muricata L (family Annonaceae) is cultivated throughout the Philippines and is used by Filipino traditional healers for various ailments. The roots are used for anemia while the leaves are used for cough and colds, indigestion, dysentery, amebiasis, diarrhea, and various types of pain. ${ }^{7}$ In other tropical countries such as Indonesia, India, and Brazil, guyabano is also commonly used to treat infections such as pneumonia, urinary tract infection, and skin diseases. ${ }^{8}$ Tsaang gubat or Ebretia microphylla Lam. (synonym Carmona retusa (Vabl) Masam) (family Boraginaceae) or commonly called Philippine tea or Fukien tea, is found in the Philippines, India, Southern China, Taiwan, and the Malay Peninsula. The leaves are frequently used by traditional healers as a decoction for various types of gastrointestinal ailments such as diarrhea, vomiting, abdominal pain as well as for other indications such as insomnia, fever, cough, colds, and muscle pain. ${ }^{7}$ Sambong or Blumea balsamifera L. (family Compositae/ Asteraceae) has been proven as an effective treatment for kidney stones. ${ }^{9}$ In the Philippines, traditional healers recommend using sambong for various ailments including cough, fever, influenza, dysentery, sore throat, malaria, boils, infected umbilical cord, sore eyes, and tuberculosis. ${ }^{7}$ Ulasimang bato or Peperomia pellucida (L.) Kunth (family Piperaceae) is also known as pansit-pansitan, sinaw-sinaw, or tangon-tangon. In the Philippines and West Africa, the whole plant is used as a warm poultice for abscesses and boils. ${ }^{10}$ Other cultures use the leaf decoction to treat urinary tract infections, headache, fever, eczema, abdominal pains, and convulsions. ${ }^{11}$

Many of the folkloric uses of these 4 medicinal plants include treatment for different types of bacterial infections. Validation of folkloric uses of these herbs is the first step to determine their potential to be developed as antibacterial herbal medicines. This study aimed to determine the antibacterial activity of guyabano, tsaang gubat, sambong, and ulasimang bato against common pathogens.

\section{MATERIALS AND METHODS}

\section{Plant materials}

The 4 medicinal plants were grown and cultivated by the agricultural team of the University of the Philippines at Los Baños who also identified and authenticated the samples (Table 1). The leaves were selected, with the dirt and foreign materials removed, and were delivered to the pharmacy team at the University of the Philippines Manila. Onsite garbling was performed, then the leaves were washed with clean tap water. The leaves were then placed on drying

Table 1. Philippine medicinal plants evaluated for antibacterial activity

\begin{tabular}{|c|c|c|c|c|}
\hline Scientific name & Local name & Family & Type of extract & Microorganisms tested \\
\hline Annona muricata & Guyabano & Annonaceae & Ethanol & $\begin{array}{l}\text { S. aureus } \\
\text { E. coli }\end{array}$ \\
\hline $\begin{array}{l}\text { Ehretia microphylla } \\
\text { (syn. Carmona retusa) }\end{array}$ & Tsaang gubat & Boraginaceae & Aqueous & $\begin{array}{l}\text { S. aureus } \\
\text { E. coli } \\
\text { Shigella dysenteriae } \\
\text { Salmonella typhi }\end{array}$ \\
\hline Blumea balsamifera & Sambong & Asteraceae/Compositae & Ethanol and Aqueous & $\begin{array}{l}\text { S. aureus } \\
\text { E. coli } \\
\text { H. influenzae } \\
\text { P. aeruginosa }\end{array}$ \\
\hline Peperomia pellucida & Ulasimang bato & Piperaceae & Aqueous & $\begin{array}{l}\text { S. aureus } \\
\text { E. coli } \\
\text { H. influenzae } \\
\text { P. aeruginosa }\end{array}$ \\
\hline
\end{tabular}


beds with electric fans for 2 days at room temperature. The leaves were dried in an oven at $60^{\circ} \mathrm{C}$ until the moisture content was less than $10 \%$ and were milled into a fine powder of 0.0278 inches. $^{2}$

\section{Plant Extract Preparation}

Plant extracts were prepared at the Department of Industrial Pharmacy, College of Pharmacy, University of the Philippines Manila. The plant extracts were prepared following a modified procedure from the Philippine Pharmacopeia. ${ }^{12}$ For alcoholic extraction, ethanol was added to completely submerge the leaves at a ratio of 4:1 (ethanol: powdered leaves). The solution with the leaves was then macerated for 24 hours with frequent shaking for the first five (5) hours and then was allowed to stand for nineteen hours. The solution was filtered rapidly using Whatmann filter paper No. 1 and the filtrate was set aside. The residue was washed with ethanol and filtered again. All filtrates were combined and were subjected to freeze drying.

For aqueous extraction, distilled water was added at a ratio of 4:1 (water: powdered leaves). The solution was heated for 15 minutes to make a decoction then cooled and filtered using previously boiled cheese cloth. The residue was washed with distilled water. All filtrates were combined and subjected to secondary filtration using Whatmann filter paper No. 1. Final filtrate was lyophilized. Prior to the antibacterial screening, the extracts were rendered sterile by filtering through a 0.22 um filter disk and stored at $-20^{\circ} \mathrm{C}$ prior to use.

Originally both aqueous and ethanolic extracts of all 4 plants were planned to be tested. Unfortunately, due to time constraints and lack of plant material (it was also tested for other pharmacologic activities and toxicity studies), not all types of extracts were tested.

\section{Test Microorganisms}

The following common pathogens were used in the study: Streptococcus pneumoniae, Haemophilus influenzae, Staphylococcus aureus, Pseudomonas aeruginosa, and enteric organisms like Escherichia coli, Salmonella typhi, and Shigella flexneri. These organisms were chosen since they are the common bacteria that cause serious diseases with widespread resistance.

The isolates of Streptococcus pneumoniae and Haemophilus influenzae were obtained from the Department of Microbiology, Research Institute for Tropical Medicine (RITM). Biochemical tests were done on the isolates obtained from RITM to confirm the bacterial identity. The Escherichia coli, Staphylococcus aureus, Salmonella typhi, and Shigella flexneri clinical isolates were obtained from the Department of Medical Microbiology, College of Public Health, UP Manila and were tested for their antimicrobial susceptibility to also confirm their identities. Table 1 shows the microorganisms tested for each plant. Since tsaang gubat has been proven efficacious for abdominal colic due to gastroenteritis, evaluating for antibacterial activity against gastrointestinal pathogens was deemed important thus, Salmonella typhi and Shigella flexneri were also tested.

\section{Antibacterial assay of plant extracts}

The plant extracts were tested for antibacterial activity by determining their minimum inhibitory concentrations (MIC). Agar dilution susceptibility method described by Turnidge and Bell ${ }^{13}$ was modified. Instead of commercially available pure antimicrobial powders, the leaf plant extracts were used. Ten concentrations levels $(100,000-180 \mathrm{ug} / \mathrm{mL})$ were tested, when possible, for each plant extract and its activity was tested against the selected bacteria. The different concentrations of extract were poured onto ten different petri dishes. The correct doses of antibiotic control and negative control (triple distilled water) were used. Mueller Hinton agar was prepared according to the manufacturer's instructions (Laboratorios, Conda SA, Madrid, Spain) and cooled to $50^{\circ} \mathrm{C}$. Agar was added to each petri dish with either a dose of the plant extract, or the positive or negative control. The agar was allowed to set and the surfaces of the plates were allowed to dry for 10 minutes in a fan assisted drying cabinet without ultraviolet light.

Growth method was used for Enterobacteriaceae, Pseudomonas, Streptococci, Haemophilus, and Staphylococci. At least 4 morphologically similar colonies were transferred with a sterile loop to the Isosensitest Broth and incubated with shaking at $35-37^{\circ} \mathrm{C}$ until the visible turbidity is equal or greater than the $0.5 \mathrm{McF}$ arland Standard.

\section{Plate inoculation}

A micropipettor was used in delivering $1-2 \mathrm{uL}$ of bacterial suspension of inoculum onto the surface of the agar. The inoculums were allowed to be absorbed into the agar prior to incubation. Three replicates of each dilution were performed.

\section{Incubation conditions}

Conditions for incubation of the plates are shown in the following list:

Enterobacteriaceae $35-37^{\circ} \mathrm{C}$ in air for $18-20 \mathrm{~h}$

Pseudomonas spp $35-37^{\circ} \mathrm{C}$ in air for $18-20 \mathrm{~h}$

Staphylococci (other than tests on methicillin/oxacillin)

$35-37^{\circ} \mathrm{C}$ in air for $18-20 \mathrm{~h}$

Staphylococci tests on methicillin/oxacillin $30^{\circ} \mathrm{C}$ in air for $24 \mathrm{~h}$

S. pneumoniae $35-37^{\circ} \mathrm{C}$ in $4-6 \% \mathrm{CO} 2$ in air for $18-20 \mathrm{~h}$

Haemophilus spp. $35-37^{\circ} \mathrm{C}$ in $4-6 \% \mathrm{CO} 2$ in air for $18-20 \mathrm{~h}$

Salmonella typhi $35^{\circ} \mathrm{C}$ in air for $16-18 \mathrm{~h}$

Shigella flexneri $35-37^{\circ} \mathrm{C}$ in air for $18-24 \mathrm{~h}$

\section{Reading and Interpretation}

The Minimum Inhibitory Concentration (MIC) for the extract against a specific bacterium was the lowest concentration of extract at which there was no visible growth of the organism in 24 hours. The antibiotic-free control 
plate should have visible growth for the assay to be valid. The expected MIC was based on the breakpoints set by the European Committee on Antimicrobial Susceptibility Testing 2016 for the specific organism and antibiotic control. Strong antibacterial activity was defined as a MIC $<5 \mathrm{mg} / \mathrm{mL} .^{14}$

\section{RESULTS}

Four Philippine medicinal plants were tested for their antibacterial activity through the agar dilution method. Guyabano was only tested for 2 representative organisms. It had moderate activity against $S$. aureus which was sensitive to oxacillin with an MIC of 5-6.3 $\mathrm{mg} / \mathrm{mL}$. For ceftriaxonesensitive E. coli, it showed poor inhibitory activity for all concentrations tested up to the highest dose tested which was $15.8 \mathrm{mg} / \mathrm{mL}$.

Tsaang gubat aqueous leaf extract was tested against common enteric bacteria (Salmonella typhi, Shigella flexneri, E. coli) and S. aureus. The maximum concentration tested was $25,000 \mathrm{ug} / \mathrm{mL}$ because the extract was thick and could not be filtered to be rendered sterile. There was significant growth of all bacteria tested (ampicillinresistant Salmonella typhi, ampicillin-sensitive Shigella flexneri, ampicillin-resistant E.coli and methicillin-sensitive S.aureus) in all concentrations tested even at the maximum concentration of tsaang gubat extract.

Aqueous and alcoholic extracts of sambong were tested against all 5 resistant bacteria to a maximum concentration of $50,000 \mathrm{ug} / \mathrm{mL}$ due to the thickness of the extract (Table 2). The MICs ranged from 12.5 to $>50 \mathrm{mg} / \mathrm{mL}$, showing some antibacterial activity for the pathogens tested. S. pneumoniae had the lowest MIC using the alcoholic sambong extract.

Ulasimang bato aqueous leaf extract was tested for its antibacterial activity against resistant $S$. aureus, S. pneumoniae, H. influenzae, E. coli, and Pseudomonas aeruginosa. The ulasimang bato leaf extract did not show any antibacterial activity against both gram positive and gram negative bacteria used in the study. (Table 3 ).

\section{DISCUSSION}

There is a pressing need for new antibacterials and medicinal plants show a promising potential as source of antibacterial agents. Four common Philippine medicinal plants were tested for their antibacterial activity. Among the 4 plants, the guyabano alcoholic leaf extract showed some promise against Staphylococcus aureus, although this was a methicillin-sensitive strain. A few studies have shown diverse results. A study from Indonesia showed poorer antibacterial activity of guyabano methanol and chloroform leaf extract against $S$. aureus and $E$. coli, with the methanol extract having a zone of inhibition greater than $14 \mathrm{~mm}$ at $150 \mathrm{mg} / \mathrm{mL}$ for S. aureus and $250 \mathrm{mg} / \mathrm{mL}$ for E. coli. ${ }^{14}$ This study indicates that very high concentrations of the Indonesian guyabano
Table 2. MIC of Sambong aqueous and alcoholic extracts against common bacterial pathogens

\begin{tabular}{cccc} 
Bacteria & $\begin{array}{c}\text { MIC (mg/mL) } \\
\text { for Aqueous } \\
\text { extract }\end{array}$ & $\begin{array}{c}\text { MIC (mg/mL) } \\
\text { for Ethanol } \\
\text { extract }\end{array}$ & $\begin{array}{c}\text { Susceptibility of the } \\
\text { bacteria tested }\end{array}$ \\
S. aureus & 25 & 25 & Resistant to vancomycin \\
S. pneumoniae & $>50$ & 12.5 & Resistant to penicillin \\
H. influenzae & $>50$ & 25 & Resistant to ceftriaxone \\
E. coli & $>50$ & $>50$ & Resistant to ampicillin \\
P. aeruginosa & $>50$ & $>50$ & Resistant to ceftazidime \\
\hline
\end{tabular}

Table 3. MIC of Ulasimang bato aqueous extract against common bacterial pathogens

\begin{tabular}{|c|c|c|}
\hline Bacteria & $\mathrm{MIC} \mathrm{mg} / \mathrm{mL}$ & Susceptibility of the bacteria tested \\
\hline S. aureus & $>100$ & Bacteria resistant to vancomycin \\
\hline S. pneumoniae & $>100$ & Bacteria resistant to penicillin \\
\hline H. influenzae & $>100$ & $\begin{array}{l}\text { Bacteria resistant to ampicillin } \\
\text { and ceftriaxone }\end{array}$ \\
\hline E. coli & $>100$ & Bacteria resistant to ampicillin \\
\hline P. aeruginosa & $>100$ & Bacteria resistant to ceftazidime \\
\hline
\end{tabular}

leaf extracts are needed to produce antibacterial activity. Another study used the agar cup method in determining the antibacterial activity of Annona muricata leaf extracts. High concentrations ranging from $50-400 \mathrm{mg} / \mathrm{mL}$ were used. ${ }^{15}$ The methanolic leaf extract showed higher antibacterial activity against Streptococcus pyogenes, Staphylococcus aureus, Bacillus subtilis, Escherichia coli, Salmonella typhimurium, and Klebsiella pneumoniae with zones of inhibition greater than $14 \mathrm{~mm}$ even at the lowest dose of $50 \mathrm{mg} / \mathrm{mL}$.

In the present study, tsaang gubat was tested against several gastrointestinal bacterial pathogens. Unfortunately, at the highest dose tested $(25 \mathrm{mg} / \mathrm{mL})$, the aqueous extract did not exhibit any antibacterial activity. A study from India also revealed that tsaang gubat did not have any antibacterial activity against E. coli, Klebsiella aerogenes, Proteus vulgaris, and Pseudomonas aerogenes. ${ }^{16}$ In contrast, another study on tsaang gubat from the Philippines showed that the ethanol extract had an MIC of $1.25 \mathrm{mg} / \mathrm{mL}$ for methicillin-resistant S. aureus, vancomycin-resistant Enterococcus, and MIC of 2.5 $\mathrm{mg} / \mathrm{mL}$ for Pseudomonas aeruginosa. ${ }^{17}$ In another study from India, the methanol and chloroform leaf extract of tsaang gubat showed large zones of inhibition (17-28 mm) against Pseudomonas aeruginosa, K. pneumoniae, Shigella flexneri, and Bacillus subtilis. ${ }^{18}$ Results of the present study on the antibacterial property of tsaang gubat may not have been as effective as the study from India due to the different extraction method. A second look at the ethanolic extract may be worth repeating to see its reproducibility for the Philippine variety.

Both the aqueous and ethanolic sambong leaf extracts were tested against several common bacterial pathogens. Some antibacterial activity was seen against vancomycinresistant $S$. aureus with an MIC of $25 \mathrm{mg} / \mathrm{mL}$ and penicillin-resistant $S$. pneumoniae with an MIC of 12.5 $\mathrm{mg} / \mathrm{mL}$. Further studies may be conducted, such as those 
for less resistant bacteria to determine if an antibacterial preparation from sambong is worth pursuing. Sakee also determined the antibacterial activity of sambong but used the essential oil and other types of extracts. It was found that the essential oil had the most potent activity compared to the other extracts with an MIC of $0.12 \mathrm{mg} / \mathrm{mL}$ against S. aureus and C. albicans. ${ }^{19}$

Results from the present study also revealed that the aqueous extract of ulasimang bato showed poor antibacterial activity for the resistant bacteria tested with MIC values higher than $100 \mathrm{mg} / \mathrm{mL}$. In contrast, another study showed low MICs for all bacteria studied. MIC values ranged between $0.031 \mathrm{mg} / \mathrm{ml}$ and $0.125 \mathrm{mg} / \mathrm{mL}$. Bacteria included E. coli, Pseudomonas aeruginosa, Vibrio cholera, and Klebsiella although the sensitivity to other antimicrobials was not mentioned in the study. ${ }^{20}$ Differences in activities may be due to different varieties of plants or growth conditions leading to the production of different plant metabolites.

\section{CONCLUSION}

Among the 4 Philippine medicinal plants tested, guyabano aqueous leaf extract showed some promise as an antibacterial agent possibly for a topical indication with an MIC of $5 \mathrm{mg} / \mathrm{mL}$ for methicillin-sensitive S.aureus. The aqueous leaf extracts of 3 other plants (sambong, tsaang gubat, and ulasimang bato) exhibited poor activity for the resistant bacteria tested. However, the sambong alcoholic extract exhibited inhibitory activity against penicillinresistant $S$. pnuemoniae.

\section{Acknowledgments}

We appreciate the contributions of Dr. Ernesta Quintana, Professor Constancio de Guzman, Salva Medina and Nina Evangelista for providing the plant materials used. We acknowledge the participation of our pharmacists, Associate Professor Jocelyn Palacpac, Mr. Essel Tolosa, and Mr. Jade Rodriguez who formulated the plant extracts used in this study. We also acknowledge the participation of Azita Racquel Lacuna for her assistance during the performance of the experiments.

\section{Statement of authorship}

All authors participated in drafting the protocol. Cavinta and Sara were involved in data collection. Maramba, Cavinta and Sara were involved in data analysis. All authors were involved in writing the manuscript and approved the final version submitted.

\section{Authors disclosure}

All authors declared no conflict of interest.

\section{Funding source}

Funding support for the experiments of guyabano and sambong were provided by the Philippine Council for
Research and Development, Department of Science and Technology. The Funding support for the experiments on ulasimang bato and tsaang gubat were from the Philippine Institute of Traditional and Alternative Healthcare, Department of Health.

\section{REFERENCES}

1. Top 10 Causes of Morbidity [Internet]. Field Health Service Information System 2014, Epidemiology Bureau, DOH. [cited 2017 Aug]. Available from http://www.doh.gov.ph/morbidity.

2. World Health Organization. Antimicrobial Resistance Global Report on Surveillance 2014. WHO Document Production Services, Geneva, Switzerland, 2014.

3. Antimicrobial Resistance Surveillance Reference Laboratory, Department of Health- Research Institute for Tropical Medicine. Antimicrobial Resistance Surveillance Program - 2017 Data Summary Report.

4. Abreu AC, McBain AJ, Simoes M. Plants as sources of new antimicrobials and resistance-modifying agents. Nat Prod Rep. 2012; 29(9):1007-21.

5. Lewis K, Ausubel FM. Prospects for plant-derived antibacterials. Nat Biotechnol. 2006; 24(12):1504-7.

6. Willcox ML, Bodeker G. Traditional herbal medicines for malaria. BMJ. 2004; 329(7475):1156-9.

7. Quintana EG, Saraos E. Folk uses of potential medicinal plants in the Philippines: a survey (CD) Los Baños, Laguna: University of the Philippines at Los Baños, 2003.

8. Leslie Taylor, The Healing Powers of Herbs, reprinted in the Technical Data Report for Graviola (Annona muricata). Sage Press Inc, Austin Texas. 2005.

9. Dantes MB, editor. Philippine National Formulary Manual for Primary Healthcare, 8th edition, 2014; p. 106.

10. Quisumbing E. Medicinal Plants of the Philippines. Quezon City: JMC Press Inc, 1978.

11. Khan A, Rahman M, Islam MS, Neuropharmacological effects of Peperomia pellucida leaves in mice. DARU J Pharm Sci. 2008; 16(1):35-40.

12. Department of Health- Bureau of Food and Drug, Philippine Pharmacopoeia 1, 2004. Manila, Philippines, DOH-BFAD; p. 182.

13. Turnidge JD, Bell JM. Antimicrobial Susceptibility on Solid Media. In: Lorian V, ed. Antibiotics in Laboratory Medicine, 5th ed. Philadelphia:Lippincott Williams and Wilkins; 2005. pp. 12-30.

14. Bussmann RW, Malca-Garcia G, Glenn A, Sharon D, Chait G, Diaz $\mathrm{D}$, et al. Minimum inhibitory concentrations of medicinal plants used in Northern Peru as antibacterial remedies. J Ethnopharmacol. 2010; 132(1):101-8.

15. Haro G, Utami NP, Sitompul E. Study of the antibacterial activities of Soursop (Annona muricata L.) leaves. Int J Pharmtech Res. 2014; 6(2):575-81.

16. Solomon -Wisdom GO, Ugoh SC, Mohammed B. Phytochemical screening and antimicrobial activities of Annona muricata (L) leaf extract. Am J Biol Chem Pharm Sci. 2014; 2(1):1-7.

17. Samy RP, Ignacimuthu S, Sen A. Screening of 34 Indian medicinal plants for antibacterial properties. J Ethnopharmacol. 1998; 62(2):173-82.

18. Valle DL, Andrade JI, Puzon JJM, Cabrera E, Rivera WL. Antibacterial activities of ethanol extracts of Philippine medicinal plants against multi-drug resistant bacteria. Asian Pac J Trop Biomed. 2015; 5(1):930-7.

19. Chandrappa CP, Govindappa M, Kumar NVA. Phytochemical screening and antibacterial property of Carmona retusa (Vahl) Masam. Int J Pharm Med Biol Sci. 2012; 1 (2): 91-98.

20. Wei LS, Wee W, Siong JY, Syamsumir DF. Characterization of anticancer, antimicrobial, antioxidant properties and chemical compositions of Peperomia pellucida leaf extract. Acta Med Iran. 2011; 49(10):670-4. 